\title{
$\mathrm{J}_{\mathrm{AN}} \mathrm{STOKSIK}^{1}$
}

\section{Wybrane zagadnienia ochrony interesów finansowych Unii Europejskiej w dziedzinie Wspólnej Polityki Rolnej}

Ochrona interesów finansowych Unii Europejskiej (dalej UE) jest obowiązkiem wszystkich podmiotów uczestniczących w procesie dystrybucji funduszy unijnych. Obowiązek ten w równej mierze dotyczy zarówno podmiotów krajowych, jak też unijnych. W szczególności na państwach członkowskich korzystających z pomocy unijnej spoczywa obowiązek przyjęcia regulacji prawnych zapewniających skuteczną ochronę interesów finansowych UE poprzez zapewnienie prawdziwości oraz prawidłowości operacji finansowych, zapobieganie nieprawidłowościom, odzyskiwanie kwot utraconych na skutek nieprawidłowości i zaniedbań i wreszcie ustanowienie skutecznego systemu zarządzania i kontroli.

Zakres regulacji prawnych dotyczących funduszy unijnych, w tym także finansujących mechanizmy Wspólnej Polityki Rolnej (dalej WPR), jest niezwykle obszerny. Nie jest zatem rzeczą możliwą dokonanie całościowej i w miarę wyczerpującej analizy tych regulacji w ramach ograniczonego objętościowo referatu na konferencję naukową. $Z$ tego też powodu problematyka rozważań w nim zawartych musiała zostać ograniczona, zgodnie zresztą z tematem referatu, do najważniejszych, wybranych tylko zagadnień w zakresie ochrony interesów finansowych UE. Autor niniejszej pracy ma jednak nadzieję, że prezentowane w niej rozważania i poglądy będą stanowić prowokujący do dyskusji przyczynek zarówno nad pozytywnymi, jak i negatywnymi doświadczeniami w zakresie skutecznej ochrony interesów finansowych UE, niekoniecznie tylko w dziedzinie WPR.

\section{Finansowanie Wspólnej Polityki Rolnej}

Od 2007 roku instrumenty WPR finansowane są przez dwa nowe fundusze rolne UE, a mianowicie:

- Europejski Fundusz Rolniczy Gwarancji (dalej EFRG) oraz

1 Uniwersytet Kardynała Stefana Wyszyńskiego w Warszawie. 
Wybrane zagadnienia ochrony interesów finansowych Unii Europejskiej w dziedzinie...

- Europejski Fundusz Rolny na rzecz Rozwoju Obszarów Wiejskich (dalej EFRROW). ${ }^{2}$

Powołanie do życia dwóch odrębnych funduszy rolnych ukierunkowało dystrybucję środków unijnych na finansowanie instrumentów należących do dwóch zasadniczych nurtów WPR, jakie ukształtowały się w ponad 50-letnim już okresie jej funkcjonowania. Tak więc EFRG finansuje obecnie instrumenty $\mathrm{z}$ nurtu polityki rynkowo-dochodowej, zaś EFRROW instrumenty z nurtu polityki strukturalnej. ${ }^{3}$ Obydwa te fundusze posiadają z jednej strony pewne elementy wspólne co do sposobu ich zarządzania (np. w zakresie rozliczania rachunków przez tzw. agencje płatnicze), w określonych natomiast przypadkach ich wyodrębnienie pozwala na odmienne, z uwagi na specyfikę konkretnych działań, podejście. Odnosi się to w szczególności do działań przewidzianych programami rozwoju obszarów wiejskich, które choć powoli, ale jednak sukcesywnie nabierają większego znaczenia $\mathrm{w}$ aktualnie podejmowanych działaniach WPR.

Za powołaniem do życia dwóch nowych funduszy rolnych przemawiały również trudności we wdrażaniu różnych form pomocy finansowej, pochodzącej z jednego źródła, jakim był utworzony w 1962 roku Europejski Fundusz Orientacji i Gwarancji Rolnej. ${ }^{4}$ Trudności tych nie wyeliminował podział tego Funduszu na dwie Sekcje (Gwarancji oraz Orientacji), dokonany na mocy rozporządzenia Rady nr 17/64. ${ }^{5}$

Nowe fundusze rolne poddane zostały ostrzejszemu reżimowi rozliczeń w zakresie wydatkowanych środków, m.in. poprzez coroczną procedurę rozliczania rachunków agencji płatniczych. Ta zasada dokonywania rozliczeń dotyczyła poprzednio tylko działań podejmowanych w ramach Sekcji Gwarancji poprzedniego Funduszu. Rozliczanie działań podejmowanych w ramach Sekcji Orientacji odbywało się w ramach wieloletnich programów pomocowych zgodnie z zasadami dokonywania rozliczeń w ramach funduszy strukturalnych UE. ${ }^{6}$

Obydwa nowe fundusze rolne, finansując mechanizmy WPR, różnią się między sobą charakterem realizowanego w ich ramach wsparcia. Tak więc środki EFRG wydatkowane są na bezpośrednie wsparcie działalności rolniczej, głównie w formie płatności bezpośrednich dla rolników. Z kolei środki EFRROW, choć formalnie nie zostały obecnie zaliczone do grupy funduszy strukturalnych, to jednak faktycznie kierowane są na wspólfinansowanie przedsięwzięć prowadzących do przekształceń strukturalnych w rolnictwie i na terenach wiejskich, zwłaszcza w państwach i regio-

Powołane do życia na mocy art. 2 ust. 1 rozporządzenia Rady (WE) nr 1290/2005 z 25 czerwca 2005 r., Dz.U. UE nr L 209.

3 Więcej na ten temat zob. K. Kozikowska, (w:) M. Jarosiewicz, K. Kozikowska, M. Wujczyk, Prawo rolne, Warszawa 2011, s. 192 i nast.

Rozporządzeniem Rady (WE) nr 25/62 , Dz.U. WE 1962, 992/62.

Dz.U. WE 1964, s. 117.

Zgodnie z przepisami rozporządzenia Rady (WE) nr 1260/1999 z dnia 21 czerwca 1999 roku wprowadzającego ogólne przepisy dotyczące funduszy strukturalnych, Dz.U. WE nr L 161 z 26 czerwca 1999 roku. 
nach słabiej rozwiniętych. Obydwa te fundusze odróżnia jeszcze to, że mechanizmy WPR finansowane $\mathrm{z}$ pierwszego $\mathrm{z}$ nich co do zasady $\mathrm{w}$ całości pokrywane są $\mathrm{z}$ jego środków, zaś działania wspierane przez drugi fundusz są w części współfinansowane ze środków krajowych, lokalnych oraz ze środków własnych ich beneficjentów.

Na użytek rozważań zawartych w niniejszej pracy warto też wskazać na zasadnicze kierunki wydatkowania środków z obu analizowanych tutaj funduszy rolnych. Tak więc zgodnie z art. 3 rozporządzenia Rady (WE) nr 1290/2005 z EFRG finansuje się przede wszystkim:

- płatności bezpośrednie dla rolników,

- interwencję w zakresie regulacji rynków rolnych,

- refundację w przypadku wywozu produktów rolnych do państw trzecich,

- promocję produktów rolnych na wewnątrzunijnym rynku oraz na rynkach państw trzecich,

- wydatki związane z rachunkowością rolniczą i systemem badań rolnych.

Fundusz ten, zgodnie z przepisami przywołanego wyżej artykułu, finansuje również w sposób scentralizowany inne jeszcze wydatki.

Z kolei EFRROW, zgodnie z art. 4 przywołanego wyżej rozporządzenia Rady (WE) wnosi wkład finansowy Wspólnoty w programy rozwoju obszarów wiejskich, wdrażane zgodnie z ustawodawstwem wspólnotowym. Zgodnie z nim środki wypłacane z tego funduszu mają na celu zrównoważony rozwój rolnictwa i leśnictwa, poprawę konkurencyjności gospodarki rolno-żywnościowej, wzrost zatrudnienia poprzez rozwój przedsiębiorczości, poprawę stanu środowiska naturalnego, rozwój turystyki, rozbudowę infrastruktury na terenach wiejskich, ułatwienie dostępu do usług oraz podniesienie jakości życia ludności zamieszkującej obszary wiejskie. ${ }^{7}$

\section{Podstawy prawne pozyskiwania funduszy rolnych Unii Europejskiej}

Podstawy prawne pozyskiwania funduszy wspólnotowych zawierały już przepisy prawa traktatowego, poczynając od Traktatu Rzymskiego z 1957 roku ustanawiającego Europejską Wspólnotę Gospodarczą, poprzez Jednolity Akt Europejski z 1986 roku, Traktat z Maastricht o Unii Europejskiej z 1992 roku, Traktat Nicejski z 2001 roku, Traktat Lizboński z 2007 roku, po umowy o przystąpieniu do UE no-

Zob. zwłaszcza art. 3 i 4 rozporządzenia Rady (WE) nr 1698/2005. Dla pełniejszej ilustracji prowadzonych rozważań warto wskazać na kwoty środków finansowych postawionych do dyspozycji Polsce w bieżącej perspektywie finansowej. Tak więc z EFRG przewidziano do wykorzystania kwotę 13,5 mld euro, zaś z EFRROW 13,3 mld euro. Warto też zauważyć, że struktura wydatków na realizację WPR charakteryzuje się zdecydowaną przewagą środków kierowanych na finansowanie mechanizmów z nurtu polityki rynkowo-dochodowej. 
wych państw członkowskich. ${ }^{8}$ Podstawowy trzon regulacji prawnych w tym zakresie stanowią jednak liczne unijne akty normatywne prawa wtórnego.

Jak to już wyżej wspomniano, największą część środków przeznaczonych na wspieranie unijnego rolnictwa kieruje się na finansowanie różnych form wsparcia bezpośredniego, zwłaszcza na dopłaty bezpośrednie. Szczegółowe zasady stosowania tych form wsparcia regulują różne akty prawa unijnego, poczynając od przywołanego już wyżej rozporządzenia Rady nr 1290/2005. Z innych, szczegółowych już rozporządzeń rozwijających przepisy powyższego rozporządzenia wymienić w szczególności należy: modyfikowane wielokrotnie rozporządzenie Rady nr 1782/2003 z dnia 29 września 2003 roku ustanawiające wspólne zasady dla systemów wsparcia bezpośredniego w ramach WPR i ustanawiające określone systemy wsparcia dla rolników oraz zmieniające niektóre rozporządzenia Rady EWG i WE. ${ }^{9}$

Doświadczenia wyniesione z wdrażania przywoływanego wyżej rozporządzenia Rady (WE) nr 1782/2003 pokazały, że niektóre elementy mechanizmów wsparcia bezpośredniego wymagały skorygowania. W tej sytuacji zastąpiono je nowym rozporządzeniem Rady (WE) nr 73/2009 z dnia 19 stycznia 2009 roku ustanawiającym wspólne zasady dla systemów wsparcia bezpośredniego dla rolników w ramach wspólnej polityki rolnej i ustanawiające określone systemy wsparcia dla rolników, zmieniające rozporządzenia (WE) nr 1290/2005, nr 246/2006, nr 378/2007 oraz uchylające rozporządzenie (WE) $\mathrm{nr} 1782 / 2003 .{ }^{10}$ Rozporządzenie to zostało także kilkakrotnie zmienione.

Wsparcie rynków rolnych środkami EFRG reguluje w szczególności rozporządzenie Rady (WE) 1234/2007 ustanawiające wspólną organizację rynków rolnych. ${ }^{11}$

Wśród aktów normatywnych prawa unijnego, dotyczących polityki rozwoju obszarów wiejskich, wskazać w szczególności należy przywołane już wyżej rozporządzenie Rady (WE) nr 1698/2005.

Wsparcie finansowe rolnictwa i terenów wiejskich z funduszy unijnych regulowane przepisami prawa krajowego znalazło swe miejsce w szeregu mniej lub bardziej obszernych regulacjach krajowych. Tak więc płatności bezpośrednie regulowane są ustawą z dnia 26 stycznia 2007 roku o płatnościach w ramach systemów wsparcia bezpośredniego. ${ }^{12} \mathrm{Z}$ kolei interwencję na rynkach rolnych reguluje ustawa z dnia 11 marca 2004 roku o Agencji Rynku Rolnego i organizacji niektórych

Traktaty przywołane w tym akapicie zostały opublikowane (w:) Traktat Rzymski - tekst pierwotny nie został opublikowany; Jednolity Akt Europejski, Dz.U.(WE) L 169; Traktat z Maastricht, wersja skonsolidowana, Dz.U. UE C 115 z 9 maja 2008 r.; Traktat Nicejski, Dz.U. WE C 80 z 10 marca 2001 r.; Traktat z Lizbony, Dz.U. UE C 306 z 17 grudnia $2007 \mathrm{r}$.

10 Dz.U. UE nr L 30 z 31 stycznia 2009 roku.

11 Dz.U. UE nr L 299/1z 16 listopada 2007 roku

12 Dz.U. Nr 35, poz. 271 ze zm. 
rynków rolnych. ${ }^{13}$ Wreszcie działania w zakresie rozwoju obszarów wiejskich w latach 2007-2013 reguluje ustawa z dnia 7 marca 2007 roku o wspieraniu rozwoju obszarów wiejskich z udziałem środków EFRROW. ${ }^{14}$ Zasady uruchamiania środków z przywołanych wyżej unijnych funduszy rolnych reguluje ustawa z dnia 22 września 2006 roku o uruchamianiu środków pochodzących z budżetu UE przeznaczonych na finansowanie wspólnej polityki rolnej. ${ }^{15}$ Przepisy przywołanych wyżej ustaw znalazły z kolei swoje rozwinięcie w szeregu aktach wykonawczych rangi rozporządzeń Rady Ministrów oraz rozporządzeń Ministrów: Rolnictwa i Rozwoju Wsi (dalej MRiRW) oraz Finansów (dalej MF).

Na zakończenie prezentacji unijnego i krajowego prawodawstwa dotyczącego finansowania WPR wskazać należy jeszcze dwa akty normatywne mające istotne znaczenie dla ochrony interesów finansowych UE. Pierwsze z nich to rozporządzenie Rady (WE, Euratom) nr 2988/95 z dnia 18 grudnia 1995 roku w sprawie ochrony interesów finansowych Wspólnot Europejskich. ${ }^{16}$ Drugie natomiast, to rozporządzenia Rady (WE, Euratom) nr 2185/96 z dnia 11 listopada 1996 roku w sprawie kontroli na miejscu oraz inspekcji przeprowadzanych przez Komisję w celu ochrony interesów finansowych Wspólnot Europejskich przed nadużyciami finansowymi i innymi nieprawidłowościami. ${ }^{17}$

Godzi się w kolejności zauważyć, że wielość polityk i wspieranie ich mechanizmów poprzez fundusze unijne może prowadzić do takich nieprawidłowości natury systemowej, jak brak spójności podejmowanych działań a konsekwencji prowadzić do finansowania projektów z różnych źródeł. Potrzebę podejmowania spójnych oraz zgodnych z politykami wspólnotowymi działań, nakazują przepisy prawa unijnego, w tym przywoływanego tutaj rozporządzenia Rady (WE) nr 1698/2005. ${ }^{18}$ Spójność pomiędzy funduszami unijnymi mają zabezpieczać strategiczne wytyczne Wspólnoty dla spójności oraz krajowe plany strategiczne. ${ }^{19}$ Wytyczne Wspólnoty określają m.in. sposób, w jaki państwa członkowskie mogą wykorzystywać pomoc unijną w ramach przyjętych programów pomocowych. Jeśli zaś chodzi o przeciwdziałanie podwójnemu finansowaniu projektów, to wyznacza się w tym zakresie tzw. linie demarkacyjne pomiędzy programami operacyjnymi. Wyznaczają one kryteria rozgraniczające dopuszczalną interwencję $\mathrm{z}$ funduszu strukturalnego i wskazują rodzaj projektu oraz fundusz, z jakiego może być on dofinansowany. Rozgraniczać programy można według zasięgu terytorialnego projektów, wartości projektów, rodzaju beneficjentów, rodzaju działalności gospodarczej itd. Przeciwdziałaniu podwój-

Tekst jedn. Dz.U. z 2007 r. Nr 231, poz. 1702 ze zm.

Dz.U. Nr 64, poz. 427 ze zm.

Dz.U. Nr 187, poz. 1381 ze zm.

Dz.U. (WE) nr L 312 z 23 grudnia 1995 roku.

Dz.U. (WE) nr L 292/2 z 15 listopada 1996 roku.

Zob. pkt 6 preambuły powyższego rozporządzenia.

Strategiczne wytyczne Wspólnoty w tej sprawie zostały przyjęte decyzją Rady (WE) z dnia 6 października 2006 roku, Dz.U. UE nr L 291/11 
nemu finansowaniu projektów służą także takie mechanizmy oraz czynności, jak: kontrole krzyżowe pomiędzy programami pomocowymi oraz pomiędzy działaniami w ramach samych tych programów, oświadczenia beneficjentów o niepobieraniu pomocy na sfinansowanie projektu z innych źródeł publicznych itd. W Polsce za prawidłowe funkcjonowanie linii demarkacyjnych odpowiadają: Komitet Koordynacyjny Narodowe Strategiczne Ramy Odniesienia oraz instytucje zarządzające poszczególnymi programami. ${ }^{20}$

Racjonalne wydatkowanie środków z budżetu UE wiąże się ściśle z zagadnieniem sprawnego zarządzania finansami unijnymi. Zarządzanie to można sprowadzić do trzech poniższych zasad. Pierwsza z nich, zasada gospodarności nakazuje wydatkowanie środków we właściwym czasie i we właściwej ilości, przy jednoczesnym zachowaniu wysokiej jakości zamówień towarów i usług, które w przypadku jednostek sektora publicznego powinny być dokonywane w trybie przepisów o zamówieniach publicznych. Kolejna z nich - zasada efektywności nakazuje, aby wydatkowanie finansowych środków unijnych prowadziło do osiągania jak najlepszych efektów w realizacji celów polityk UE. Osiąganie wyznaczonych celów, wymiernych w czasie i co do ich zakresu, przy pomocy uruchamianych środków finansowych jest treścią trzeciej zasady, określanej jako zasada skuteczności. Realizacji tej zasady służyć mają oceny ex ante i ex post, prowadzone przed i po realizacji programów pomocowych. ${ }^{21}$

\section{Instytucje obsługujące mechanizmy Wspólnej Polityki Rolnej w Polsce}

Z myślą o zapewnieniu jak najpełniejszej ochrony interesów finansowych Unii Europejskiej został utworzony rozbudowany system obsługi mechanizmów WPR. W Polsce składa się na niego system instytucjonalnej obsługi WPR, sprawowany przez zobowiązane do tego instytucje państwowe, przede wszystkich przez MRiRW, MF oraz różne podmioty wdrażające i agencje płatnicze. W ramach tego systemu MRiRW oraz MF pełnią funkcję instytucji zarządzających mechanizmami pomocowymi. Kolejna grupa podmiotów to instytucje wdrażające mechanizmy pomocowe. W tej grupie znajdują się: Agencja Restrukturyzacji i Modernizacji Rolnictwa (dalej ARiMR), Agencja Rynku Rolnego (dalej ARR), samorządy województw, Fundacja Programów Pomocy dla Rolnictwa. Trzecia grupa podmiotów to instytucje płatnicze, a tę funkcję sprawują: ARiMR oraz ARR. Odrębną funkcję, z uwagi na charak-

20 Narodowe Strategiczne Ramy Odniesienia to dokument strategiczny, odpowiednik Krajowego Planu Strategicznego Rozwoju Obszarów Wiejskich w dziedzinie polityki spójności. W tej sprawie por. również dokument: Linia demarkacyjne pomiędzy programami Polityki Spójności, Wspólnej Polityki Rolnej i Wspólnej Polityki Rybackiej. Ministerstwo Rozwoju Regionalnego, www.mrr.gov.pl/fundusze europejskie/linia demarkacyjna. 21 Por. ocenę ex ante uwzględniającą doświadczenia przeszłych i obecnych programów związanych z rozwojem
obszarów wiejskich w Polsce, zawartą w treści PROW 2007-2013. 
ter podejmowanych działań, pełni instytucja certyfikująca rachunki funduszy rolnych UE. Jest nią Generalny Inspektor Kontroli Skarbowej.

Wśród instytucji zarządzających środkami finansowymi unijnych funduszy rolnych szczególna rola przypada MRiRW. W tym zakresie minister opracowuje, wdraża oraz dokonuje oceny realizacji Programu Rozwoju Obszarów Wiejskich na lata 2007-2013. Określa też szczegółowe warunki, zasady, formy oraz tryb przyznawania pomocy w pozostałych mechanizmach WPR. Jest też organem nadzoru nad dwiema podległymi mu agencjami, tj. ARiMR oraz ARR w zakresie wykorzystania przez nie środków pochodzących z funduszy UE. ${ }^{22}$

Druga z instytucji zarządzających, MF, sprawuje nadzór nad wykonywaniem przez obydwie przywoływane tutaj agencje w zakresie realizowania przez nie funkcji agencji płatniczych środków pochodzących z EFRG i EFRROW. Sprawowany tutaj nadzór obejmuje przede wszystkim udzielanie obu tym agencjom statusu agencji płatniczej oraz certyfikację ich wydatków.

Instytucje wdrażające to kolejna grupa podmiotów z systemu wdrażania mechanizmów WPR. Wdrażają one w imieniu instytucji zarządzającej działania przewidziane Programem Rozwoju Obszarów Wiejskich na lata 2007-2013 (dalej PROW 2007-2013). W zakresie podejmowanych czynności wdrażających podmioty te ogłaszają nabory wniosków o przyznanie pomocy w ramach uruchamianych działań, dokonują oceny tych wniosków i wydają decyzje lub podpisują umowy z wnioskodawcami, monitorują realizację przyjętych do wsparcia projektów, przedkładają do agencji płatniczej wnioski o płatności i dokonują płatności oraz sporządzają wymagane w tym zakresie sprawozdania. Podmiotami wdrażającymi działania PROW 2007-2013 są przede wszystkim ARiMR oraz w odniesieniu do niektórych działań Fundacja Programów Pomocy dla Rolnictwa (dalej FAPA), ARR oraz samorządy województw.

Ważne funkcje w procesie wdrażania mechanizmów WPR pełnią agencje płatnicze. Podstawę prawną ich funkcjonowania stanowią przepisy rozporządzenia KE (WE) nr 885/2006 z dnia 21 czerwca 2006 roku ustanawiające szczegółowe zasady stosowania rozporządzenia Rady (WE) nr 1290/2006 w zakresie akredytacji agencji płatniczych i innych jednostek, jak również rozliczenia rachunków EFGR i EFRROW. ${ }^{23}$ Zauważyć tutaj należy, że tylko akredytowana agencja płatnicza może dokonywać płatności dla beneficjentów funduszy unijnych i rozliczać je z KE.

Zgodnie z art. 6 przywoływanego rozporządzenia Rady (WE) nr 1290/2006 agencjami płatniczymi mogą być służby bądź organy państw członkowskich, które w zakresie dokonywanych przez siebie płatności oraz przekazywania i przechowy- 
wania informacji, w ocenie organu udzielającego akredytacji oferować będą wysoko wystarczające gwarancje do realizowania wyznaczonych im zadań. W Polsce funkcję agencji płatniczych dla unijnych funduszy rolnych pełnią: $\mathrm{ARiMR}^{24}$ oraz ARR. ${ }^{25}$

Agencje płatnicze mogą być akredytowane przez państwa członkowskie pod warunkiem, że spełniają minimalne kryteria ustanowione na poziomie Wspólnoty, obejmujące cztery podstawowe obszary: środowisko wewnętrzne, działania kontrolne, informację i komunikację oraz monitorowanie. Państwa członkowskie mogą ustanawiać dodatkowe kryteria akredytacyjne w celu uwzględnienia w danym przypadku specyfiki konkretnej agencji płatniczej.

Przechodząc do kwestii bardziej szczegółowych wiążących się z kryteriami akredytacyjnymi, wypada pokrótce wyjaśnić zakres wymogów akredytacyjnych, jakie powinna spełniać agencja płatnicza w każdym z czterech przywołanych wyżej obszarów. ${ }^{26}$ Jak chodzi o obszar ,środowisko wewnętrzne”, to wymagania akredytacyjne nakazują, aby agencja płatnicza dysponowała strukturą organizacyjną pozwalającą jej wykonywać, w odniesieniu do wydatków EFRG i EFRROW, następujące główne zadania:

1) zatwierdzanie płatności i ich kontrolę w celu ustalenia, w szczególności poprzez kontrole administracyjne i kontrole na miejscu, czy kwota, która zostanie wypłacona wnioskującemu, jest zgodna z zasadami wspólnotowymi,

2) dokonywanie płatności, których celem jest wypłacenie zatwierdzonej kwoty wnioskującemu lub, w przypadku rozwoju obszarów wiejskich, części wspólfinansowania wspólnotowego,

3) księgowanie płatności, którego celem jest rejestracja wszystkich wydatków EFRG i EFRROW na oddzielnych rachunkach agencji, które mają formę elektronicznego systemu przetwarzania danych oraz przygotowanie okresowych zestawień wydatków, łącznie z miesięcznymi, kwartalnymi, rocznymi deklaracjami kierowanymi do KE. Na rachunkach rejestrowane są również operacje finansowane przez Fundusz, w szczególności dotyczące zapasów interwencyjnych, nierozliczonych zaliczek, zabezpieczeń oraz dłużników.

Te trzy główne grupy zadań agencji płatniczej powinny być wyraźnie rozdzielone na wszystkich jej poziomach struktury organizacyjnej, zarówno co do zakresu uprawnień, jak i odpowiedzialności. W obszarze tym znajdują się służby techniczne oraz audytu wewnętrznego. Kryteria akredytacyjne dotyczące tego obszaru zawie-

24 Na podstawie przepisów rozporządzenia MFz dnia 9 listopada 2006 roku w sprawie przyznania ARiMR akredytacji jako agencji płatniczej [...], Dz.U. Nr 204, poz. 1506.

25 Na podstawie przepisów rozporządzenia MFz dnia 9 listopada 2006 roku w sprawie przyznania ARR akredytacji jako agencji płatniczej [...], Dz.U. Nr 204, poz. 1507.

26 Określa je szczegółowo cytowane rozporządzenie Komisji (WE) nr 885/2006 (zob. zwłaszcza załączniki do tego rozporządzenia). 
rają również szczegółowe normy co do zasobów ludzkich, m.in. w zakresie podziału obowiązków, ich identyfikacji, zakresu odpowiedzialności, wymaganych kwalifikacji itd.

Drugi obszar kryteriów akredytacyjnych obejmuje wymogi w zakresie pełnionych w agencji płatniczej działań kontrolnych. W tym zakresie przepisy analizowanego tutaj rozporządzenia Komisji (WE) wymagają stosowania w agencjach płatniczych szczegółowych, odrębnych następujących procedur: zatwierdzania wniosków, płatności, księgowania, zaliczek i zabezpieczeń oraz dochodzenia długów. Procedury te powinny być ujęte w odrębne książki procedur, mające charakter regulacji wewnętrznych oraz obowiązujący w konkretnej agencji płatniczej.

Informacja i komunikacja, jako kolejny obszar kryteriów akredytacyjnych, nakazuje, aby procedury obowiązujące w agencji płatniczej gwarantowały przepływ w odpowiednim czasie informacji co do zmian w przepisach Wspólnoty, zaleceń baz danych, list kontrolnych. Bezpieczeństwo systemów informacyjnych ma się opierać na kryteriach jednej z norm uznanych na poziomie międzynarodowym. ${ }^{27}$

Wreszcie obszar monitorowania czynności płatniczych w agencji płatniczej ma zapewniać po pierwsze, stałe monitorowanie za pośrednictwem wewnętrznych, bieżących działań kontrolnych, a po wtóre, agencja płatnicza ma również zabezpieczać funkcjonowanie oddzielnego rodzaju monitorowania swych działań poprzez służby niezależnego od innych wydziałów audytu wewnętrznego, podlegającego bezpośrednio jej kierownictwu.

W Polsce funkcję agencji płatniczej EFRROW dla wszystkich działań PROW 2007-2013 pełni ARiMR. Agencja ta pełni również funkcję agencji płatniczej EFRG w zakresie systemu wsparcia bezpośredniego. Funkcję agencji płatniczej w odniesieniu do pozostałych mechanizmów WPR finansowanych z EFRG pełni ARR. ${ }^{28}$

W systemie wdrażania mechanizmów WPR ważna rola przypada Generalnemu Inspektorowi Kontroli Skarbowej, który dokonuje certyfikacji i poświadczeń zamknięcia wydatków EFRG oraz EFRROW. Certyfikacja polega na zatwierdzaniu rachunków akredytowanej agencji płatniczej w zakresie ich prawdziwości, kompletności oraz dokładności, biorąc pod uwagę wprowadzony system zarządzania i kontroli (art. 7 rozporządzenia Rady (WE) nr 1290/2005). Obowiązkiem jednostki certyfikującej jest również informowanie KE o powstałych nieprawidłowościach w gospodarowaniu funduszami unijnymi.

Np. Międzynarodowej Organizacji Standaryzacji 27002: Kodeks praktyki dla zarządzania bezpieczeństwem informacji (ISO). 


\section{Zintegrowany System Zarządzania i Kontroli}

Jednym z warunków akredytacji agencji płatniczej jest posiadanie przez nią skutecznego systemu zarządzania i kontroli. Celem tego systemu jest przede wszystkim zapewnienie zgodności udzielanego przez tę agencję wsparcia finansowego z przepisami prawa wspólnotowego oraz krajowego. Ponadto system ten w sposób istotny wspomaga proces obsługi wniosków o pomoc z funduszy unijnych, a więc także przywoływanych wyżej funduszy rolnych. Ta ostatnia funkcja ma szczególne znaczenie dla ujednolicenia praktyki wdrażania pomocy unijnej nie tylko w naszym kraju, ale także w całej UE. Generalnie systemy zarządzania i kontroli określają zasady ewidencjonowania wniosków o pomoc, weryfikacji kwalifikowalności beneficjentów oraz projektów, rejestrują dokonane płatności oraz zobowiązania beneficjentów.

Przyjęty w Polsce system zarządzania i kontroli wspomaga obsługę płatności bezpośrednich i innych płatności obszarowych oraz zwierzęcych, a także mechanizmy pomocowe rozwoju obszarów wiejskich.

Z myślą o przybliżeniu istoty uruchomionego w Polsce systemu zarządzania i kontroli wypadnie w kolejności wskazać na najważniejsze elementy i zasady jego funkcjonowania. Tak więc przyjęty Zintegrowany System Zarządzania i Kontroli (IACS) ${ }^{29}$ zgodnie z przepisami rozporządzenia Rady (WE) nr 1782 z dnia 29 września 2003 r., ${ }^{30}$ zawiera następujące elementy:

- skomputeryzowaną bazę danych, zawierającą dla każdego gospodarstwa rolnego dane uzyskane z wniosków o pomoc,

- system identyfikacji działek rolnych ustanawiany na podstawie map lotniczych bądź satelitarnych albo dokumentów ewidencji gruntów lub innych danych kartograficznych (mapy sporządzane są przy zastosowaniu jednolitego standardu gwarantującego dokładność co najmniej równoważną kartografii w skali 1:10 000),

- system ewidencji zwierząt gospodarskich,

- system identyfikacji i rejestracji uprawnień do płatności pozwalający na weryfikację uprawnień oraz kontrole krzyżowe z wnioskami o pomoc i systemem identyfikacji działek rolnych,

- zintegrowany system kontroli, nej i ustanawiającego określone systemy wsparcia dla rolników oraz zmieniającego rozporządzenie (EWG) nr 2019/93,(WE) nr 1452/2001, (WE) 1453/2001, (WE) 1454/2001, (WE) 1868/94, (WE) nr 1251/1999, (WE) 1673/2000, (EWG) nr 1257/71 i (WE) nr 2529/2001 (Dz. Urz. UE L 270 z 21.10.2003, s. 1 z późn. zm.; Dz. Urz. UE polskie wydanie specjalne rozdz. 3, t. 40, s. 269, z późn. zm.). 
- jednolity system rejestrowania tożsamości każdego rolnika, który składa wniosek o pomoc.

W skomputeryzowanej bazie danych dla każdego gospodarstwa rolnego zapisywane są dane z wniosków o uzyskanie pomocy. Informacje zapisane w bazie pozwalają na szybkie i bezpośrednie sprawdzenie prawdziwości danych podawanych przez rolnika w kolejnym wniosku o pomoc.

Z kolei system identyfikacji działek rolnych utworzony został w oparciu o ewidencję gruntów i budynków prowadzoną na podstawie przepisów Prawa geodezyjnego i kartograficznego ${ }^{31}$, stanowiącą w naszym kraju oficjalny, urzędowy rejestr tych nieruchomości. Jest on wykorzystywany przede wszystkim w postępowaniu o przyznanie dopłat bezpośrednich. System ten umożliwia identyfikację działek rolnych deklarowanych przez producentów rolnych oraz kontrolę ich powierzchni (na mapach ewidencji gruntów w zestawieniu ze znajdującymi się w tym systemie danych o działkach ewidencyjnych, danych kartograficznych, zdjęć lotniczych i satelitarnych). Pozwala też ustalić faktyczną powierzchnię użytkowanych działek, rodzaj prowadzonych na nich upraw i zachowanie dobrej kultury rolnej na tych działkach.

System identyfikacji i rejestracji zwierząt ewidencjonuje znakowane indywidualnie zwierzęta gospodarskie (bydło, owce, kozy) oraz trzodę chlewną znakowaną stadnie. Dane zawarte w tym systemie wykorzystywane są w ramach kontroli administracyjnej uprawnień beneficjentów do płatności zwierzęcych, a także w przypadku niektórych działań PROW 2007-2013, gdy zachodzi potrzeba zweryfikowania stanu zwierząt w gospodarstwie rolnym.

Zintegrowany System Zarządzania i Kontroli (dalej ZSZiK) powinien być dostosowany do specyfiki i potrzeb kraju członkowskiego UE. W Polsce zasady budowy tego systemu określa ustawa z dnia 18 grudnia 2003 r. o krajowym systemie ewidencji producentów, ewidencji gospodarstw rolnych oraz ewidencji wniosków o przyznanie płatności. ${ }^{32} \mathrm{Na}$ system ten, zgodnie z art. 4 powyższej ustawy, składają się ewidencje: producentów, gospodarstw rolnych, wniosków o przyznanie płatności oraz dokumentacja związana z prowadzeniem powyższych trzech grup ewidencji.

ZSZiK obejmuje swym działaniem wszystkie wnioski o przyznanie pomocy. W ramach tej kontroli, ważnej dla ochrony interesów finansowych UE, wyróżnić można następujące typy kontroli: 
- wizualną, polegającą na tym, że weryfikacja złożonego dokumentu następuje poprzez jego sprawdzenie bez konieczności dostępu do zewnętrznych źródeł danych, także bez dostępu do danych znajdujących się w systemie,

- zgodności, polegającą na sprawdzeniu, czy dane wprowadzone do systemu odpowiadają danym znajdującym się w złożonych dokumentach,

- administracyjną, obejmującą dwa rodzaje tej kontroli:

- administracyjną prostą, polegającą na sprawdzeniu danych z wniosku, oświadczenia lub deklaracji wnioskodawcy $\mathrm{z}$ danymi istniejącymi już w systemie dla danego podmiotu,

- administracyjną krzyżową, polegającą na sprawdzeniu danych wprowadzonych na podstawie wniosku, oświadczenia lub deklaracji z danymi złożonymi przez inne podmioty w celu wykrycia ewentualnego nakładania się danych z tych dokumentów.

ZSZiK obsługuje przede wszystkim płatności bezpośrednie oraz przewidziane w PROW 2007-2013 działania: wspieranie gospodarowania na obszarach o niekorzystnych warunkach gospodarowania, program rolnośrodowiskowy, zalesianie gruntów rolnych i innych niż rolne. W odniesieniu do pozostałych działań powyższego programu system ten jest wykorzystywany w ramach dokonywania czynności kontroli krzyżowej uprawnień beneficjentów tych działań.

Postępowanie w sprawie płatności bezpośrednich prowadzone jest zgodnie z przepisami kodeksu postępowania administracyjnego. Wnioski o płatności bezpośrednie załatwiane są według procedur zaprogramowanych w ZSZiK. Zgodnie z nimi wnioski o te płatności podlegają najpierw rejestracji i są wprowadzane do systemu informatycznego. Zauważyć tutaj należy, że system informatyczny wymusza przy tym wprowadzenie wszystkich danych wymaganych w zaprogramowanej procedurze. Bez tych danych wniosek nie jest poddawany dalszej procedurze. Kolejnym etapem załatwiania wniosku jest przeprowadzenie kontroli administracyjnej. Polega ona na porównaniu deklarowanych we wniosku powierzchni działek rolnych $\mathrm{z}$ bazą referencyjną LPIS, ${ }^{33}$ także z systemem identyfikacji i rejestracji zwierząt. Realizowana na tym etapie tzw. kontrola krzyżowa ma na celu sprawdzenie czy deklarowane we wniosku powierzchnie gruntów lub zwierzęta nie są wykazane we wniosku innego producenta. Sprawdzenie to ma na celu zapobieganie podwójnemu wypłaceniu pomocy na te same grunty lub zwierzęta.

Angielski skrót: Land Parcel Identification System. Jest on bazą danych o powierzchni gruntów rolnych w Polsce. Zawiera dane o działkach ewidencyjnych, zdjęcia satelitarne i lotnicze powierzchni ziemi. Służy do identyfikowania działek zadeklarowanych we wniosku przez producentów rolnych, kontrolę ich powierzchni, rodzaj upraw i zachowanie tzw. dobrej kultury rolnej na nich. Minimalne wymagania dotyczące utrzymania gruntów w dobrej kulturze rolnej zgodnej z ochroną środowiska zostały określone w rozporządzeniu MRiRW z dnia 11 marca 2010 roku w sprawie minimalnych norm (Dz.U. Nr 39, poz. 211). 
Dopełnieniem kontroli administracyjnej oraz krzyżowej jest tzw. kontrola na miejscu. ${ }^{34}$ Ma ona na celu zbadanie zgodności zadeklarowanych przez rolnika powierzchni działek ze stanem faktycznym. Realizowane są dwie metody tej kontroli. Pierwsza to metoda inspekcji terenowej, polegająca na przeprowadzeniu wywiadu terenowego i dokonaniu pomiaru działek z zastosowaniem techniki GPS. ${ }^{35}$ Druga $\mathrm{z}$ nich to metoda FOTO, polegająca na porównaniu danych zawartych we wniosku z danymi geograficznymi i zdjęciami lotniczymi powierzchni gruntów rolnych.

Jeśli w trakcie obsługi wniosku stwierdzone zostaną jakieś błędy, nieprawidłowości lub niejasności, wówczas wnioskodawca wzywany jest do złożenia wyjaśnień. Po zatwierdzeniu wyników przeprowadzonej kontroli administracyjnej ZSZiK wylicza płatność i sporządza projekt decyzji, którą wydaje kierownik biura powiatowego ARiMR. Decyzja ostateczna skutkuje zleceniem płatności kierowanym do departamentu księgowości w centrali ARiMR, która wypłaca należności na konto bankowe beneficjentów.

Z kolei realizacja płatności przewidzianych działaniami PROW 2007-2013 zawiera również szereg elementów zabezpieczających ochronę interesów finansowych UE. W pierwszej kolejności należy zauważyć, że każde z 21 działań tego programu obsługiwane jest według odrębnej wewnętrznej procedury. Cechuje je duże zróżnicowanie, powodowane głównie różnorodnością form pomocy w odniesieniu do każdego z tych działań, a także zróżnicowaniem kryteriów kwalifikowalności beneficjentów oraz projektów. Wnioski o przyznanie pomocy składa się do podmiotów wdrażających poszczególne działania w terminach przez nie określonych. Nabór wniosków realizowany jest do wyczerpania limitu środków ustalonych dla danego naboru albo w wyznaczonym tylko okresie. Na tym etapie obsługi wniosków następuje ich rejestracja i wprowadzenie do systemu informatycznego. Ważną czynnością podejmowaną na tym etapie jest kontrola administracyjna wniosku.

Wniosek o przyznanie pomocy poddany kontroli administracyjnej badany jest pod kątem jego zgodności z celami pomocy wskazanymi w programie pomocowym oraz kryteriami przyznawana pomocy, na które składa się ocena kwalifikowalności beneficjenta oraz projektu, a także kosztów projektowanego przedsięwzięcia. ${ }^{36} \mathrm{Kon}$ troli administracyjnej towarzyszy jednocześnie kontrola krzyżowa mająca na celu eliminowanie podwójnego finansowania tego samego projektu z innego źródła pomocy unijnej. ${ }^{37}$

Zasady tej kontroli reguluje rozporządzenie Komisji (WE) nr 1122/2009, Dz.U. UE L 315/65 z 2 grudnia 2009 r. GPS - system nawigacji satelitarnej używany w tym przypadku do pomiaru powierzchni.

Zasady kwalifikowalności wydatków określa art. 71 przywoływanego rozporządzenia Rady (WE) nr 1698/2005. Kontrola kwalifikowalności kosztów przedsięwzięcia dokonywana w tym przypadku ma na celu sprawdzenie, czy wszystkie koszty przedsięwzięcia mogą być przedmiotem współfinansowania.

Skuteczność tej kontroli zabezpieczają porozumienia zawierane pomiędzy różnymi podmiotami wdrażającymi mechanizmy pomocowe w przedmiocie wzajemnego udostępniania informacyjnej bazy danych o wnioskach. 
Czynnością prowadzącą do sprawdzenia prawdziwości danych we wniosku o pomoc ze stanem faktycznym jest w przypadku wielu działań analizowanego tutaj programu wizytacja terenowa.

Etap obsługi wniosku kończy podpisanie $\mathrm{z}$ beneficjentem umowy o dofinansowanie projektu przedsięwzięcia. Ważnym elementem zabezpieczającym interesy finansowe UE jest stosowne postanowienie zawieranej umowy co do sposobu zabezpieczenia prawidłowego jej wykonywania zarówno w trakcie realizacji projektu, jak też w okresie 5 lat po jego rozliczeniu. ${ }^{38}$

Autoryzacja kolejnego wniosku beneficjenta o uruchomienia płatności częściowej lub końcowej to kolejny etap postępowania o uzyskanie wsparcia. Obejmuje on następujące czynności: rejestrację wniosku o płatność, kontrolę administracyjną i kontrolę na miejscu oraz sprawdzenie wykonania umowy i wreszcie wypłatę wsparcia, bądź odmowę wypłaty. Obsługa wniosku o płatność jest również wspomagana przez system informatyczny. Kontrola administracyjna obejmuje przede wszystkim trzy grupy sprawdzeń, a mianowicie: zgodności dokumentów finansowych z umową, kwalifikowalności kosztów projektu oraz zbadanie, czy nie zachodzi zagrożenie podwójnego finansowania projektu. Z kolei kontrola na miejscu, ma na celu sprawdzenie dokumentacji księgowej potwierdzającej kwalifikowalność kosztów, sprawdzenie zrealizowanego obiektu oraz zgodności wykorzystania inwestycji z celem pomocy.

Dwa działania PROW 2007-2013, tj. „Wsparcie gospodarowania na obszarach o niekorzystnych warunkach gospodarowania” oraz „Program rolnośrodowiskowy” rozpatrywane są równolegle z obsługą wniosku o płatności bezpośrednie. Wsparcie udzielanie w ramach tych trzech mechanizmów stosownie do przepisów art. 5 i 6 przywoływanego wyżej rozporządzenia Rady (WE) nr 73/2009 warunkowane jest od spełnienia przez beneficjentów określonych wymagań dotyczących utrzymania gruntów rolnych wchodzących w skład gospodarstwa rolnego w dobrej kulturze rolnej, zgodnej z wymogami ochrony środowiska oraz podstawowych wymogów z zakresu sposobu gospodarowania. Wymogi powyższe tworzą jeden mechanizm występujący pod wspólną nazwą , wzajemna zgodność”. ${ }^{39}$

Konsekwencją naruszenia wymagań wzajemnej zgodności jest redukcja płatności bezpośrednich, proporcjonalnie do dokonanych naruszeń. Zasady tej redukcji określa rozporządzenie Komisji (WE) nr 1122/2009 z dnia 30 listopada 2009 r. ustanawiające szczegółowe zasady wykonania rozporządzenia Rady (WE) nr 73/2009 odnośnie dozasady wzajemnej zgodności modulacji oraz zintegrowanego systemu zarządzania i kontroli $\mathrm{w}$ ramach systemów wsparcia bezpośredniego przewidzianych w wymienionym rozporządzeniu oraz wdrażania rozporządzenia Rady (WE) 
nr 1234/2007 w odniesieniu do zasady wzajemnej zgodności w ramach systemu wsparcia ustanowionego dla sektora wina. ${ }^{40}$ Tak więc $\mathrm{w}$ razie nieumyślnego spowodowania nieprawidłowości sankcją jest $\mathrm{z}$ reguły redukcja płatności o $3 \%$. W razie gdyby te nieprawidłowości powtarzały się, wówczas sankcją może być redukcja płatności do $15 \%$. Natomiast sankcją za umyślne nieprzestrzeganie wymogów jest redukcja płatności w wysokości 20\%. W przypadku działań PROW 2007-2013, do których ma zastosowanie zasada wzajemnej zgodności, sankcją w tym wypadku jest redukcja kwoty wsparcia w zależności od kwoty niezakwalifikowanej do płatności.

Przywołane wyżej rozporządzenie Komisji (WE) nr 1122/2009 przewiduje inne jeszcze sankcje dla beneficjentów płatności bezpośrednich. Zwrócić należy w szczególności uwagę na sankcje z tytułu deklarowania do wsparcia większych niż w rzeczywistości powierzchni gruntów. Tak więc w przypadku, gdy stwierdzona różnica wynosi więcej niż 3\% lub dwa hektary, ale nie więcej niż $20 \%$ zatwierdzonego obszaru, wówczas pomoc oblicza się na podstawie zatwierdzonego obszaru pomniejszonego o stwierdzoną różnicę. W przypadku, gdy różnica przekracza $20 \%$ zatwierdzonego obszaru, pomocy nie przyznaje się. Z kolei gdyby różnica ta wynosiła więcej niż 30\%, wówczas beneficjenta pozbawia się płatności za dany rok kalendarzowy. Wreszcie w przypadku, gdyby różnica ta przekraczała 50\%, wtedy beneficjent wykluczany jest z pomocy na okres 3 lat.

\section{Kontrola wydatków agencji płatniczych}

Agencje płatnicze obowiązane są do wydatkowania środków unijnych zgodnie z celem oraz przy zachowaniu wspólnotowych i krajowych warunków przyznawania pomocy. W tym zakresie działania agencji płatniczych są kontrolowane przez jej służby kontroli wewnętrznej oraz zewnętrzne organy kontrolne. Do tych ostatnich organów należy zaliczyć kontrolę skarbową oraz służby KE i Europejskiego Trybunału Obrachunkowego. Kontrola wewnętrzna agencji płatniczej powinna funkcjonować niezależnie od innych jednostek organizacyjnych i być bezpośrednio podporządkowana szefowi tej agencji. Działania tej służby są pomocne w złożeniu przez kierownika agencji płatniczej oświadczenia, że sprawozdanie finansowe $\mathrm{z}$ wydatków unijnych jest prawdziwe, wyczerpujące i przedstawia dokładny stan wydatków, a nadto, że procedury przyznawania pomocy są zarządzane, kontrolowane i dokumentowane zgodnie z przepisami wspólnotowymi. ${ }^{41}$

40 Dz.U. UE L 316/65 z 2 grudnia 2009 roku.

41 Obowiązek tego poświadczenia wynika z przepisów art 3 rozporządzenia Rady (WE) nr 885/2006 z 21 czerwca 2006 r. ustanawiającego szczegółowe zasady stosowania rozporządzenie Rady (WE) nr 1290/2005 w zakresie akredytacji agencji płatniczych i innych jednostek, jak również rozliczania rachunków EFRG i EFRROW, Dz.U. UE L 171/90 z dnia 23 czerwca 2006 r. 
Wśród zewnętrznych służb kontroli szczególna rola przypada kontroli skarbowej. Kontroluje ona wydatki agencji płatniczych z punktu widzenia ich celowości oraz zgodności z przepisami prawa określającego zasady wydatkowania środków unijnych. Do zadań tej kontroli należy również certyfikacja rachunków funduszy unijnych oraz wydawanie deklaracji zamknięcia pomocy ze środków pochodzących z Unii Europejskiej. Po zakończeniu każdego roku budżetowego Generalny Inspektor Kontroli Skarbowej wydaje świadectwo stwierdzające, że rachunki sporządzone przez agencję płatniczą i przekazywane do Komisji Europejskiej są autentyczne, kompletne i dokładne oraz że procedury kontroli w agencji płatniczej działały poprawnie. $^{42}$

\section{Próba oceny skuteczności stosowanych w Polsce rozwiązań w zakresie ochrony interesów finansowych Unii Europejskiej w dziedzinie Wspólnej Polityki Rolnej}

Zaprezentowane wyżej, w syntetycznym jedynie zarysie, najważniejsze rozwiązania prawne $w$ zakresie ochrony interesów finansowych ograniczone zostały do rozwiązań przyjętych i realizowanych w Polsce. Wielość przyjętych w tym zakresie rozwiązań obejmuje kilka obszarów zabezpieczeń należytego gospodarowania środkami unijnymi. Większoóć wdrożonych tutaj rozwiązań jest wynikiem implementacji do polskiego systemu prawnego przyjętych w tym zakresie rozwiązań unijnych.

Na sprawny system ochrony interesów finansowych UE składa się wiele czynników, poczynając od trafnie sformułowanych celów i narzędzi WPR oraz sprawnie funkcjonujący system organów wdrażających narzędzia tej polityki, dysponujących skutecznymi instrumentami ochrony prawnej tych interesów. Wydaje się, że funkcjonujący w Polsce system finansowania rolnictwa i terenów wiejskich $\mathrm{z}$ funduszy rolnych UE można najtrafniej ocenić w pryzmacie skali nieprawidłowości mających miejsce w zakresie pozyskiwania środków finansowych Unii Europejskiej. Pożyteczną w tym zakresie może być informacja złożona w styczniu bieżącego roku przez wiceprezesa ARiMR dla Polskiej Agencji Prasowej. ${ }^{43} \mathrm{~W}$ jej świetle $241 \mathrm{mln}$ zł to kwota, jaką ARiMR musi odzyskać jako należność, która powstała z tytułu nałożonego na beneficjentów obowiązku zwrotu nienależnie pobranego świadczenia, z racji dopuszczenia się przez nich różnych nieprawidłowości w pozyskiwaniu środków finansowych UE. Wysokość orzeczonych do zwrotu kwot przedstawia się następująco: z przedakcesyjnego programu SAPARD - ok. $20 \mathrm{mln}$. zł; z programów pomocowych z lat 2004-2006 - ok. $202 \mathrm{mln}$ zł; z PROW 2007-2013 ponad $13 \mathrm{mln}$ zł (wskaźnik procentowy odnoszący się odpowiednio do przywołanych wyżej kwot

42 Zadania jednostek certyfikujących formułują w szczególności przepisy art 7 i 8 przywoływanego rozporządzenia Rady (WE) nr 1290/2005.

43 Zob. $240 \mathrm{mln}$ zł do windykacji od rolników z tytułu nienależnych dopłat, (w:) „Gazeta Prawna” z 25 stycznia 2012 roku. 
należności przedstawia się następująco: 0,3, 0,7, 1,3, 0,2 ogółu środków wydatkowanych z tych programów). Powyższe wskaźniki oznaczają, że ARiMR spełnia warunki audytu, ponieważ zgodnie z przepisami prawa unijnego liczba stwierdzonych nieprawidłowości nie przekracza 2,5\%. Jeśli chodzi o rodzaj nieprawidłowości, to głównie dotyczą one niedotrzymania zobowiązania przez rolników korzystających z płatności z tytułu gospodarowania w trudnych warunkach, którego treścią był wymóg kontynuowania działalności przez co najmniej 5 lat. Inne nieprawidłowości to niedotrzymanie terminu podniesienia kwalifikacji rolniczych przez rolników w przypadku działania „,młody rolnik”, następnie złożenie podrobionych, nierzetelnych lub poświadczonych niezgodnie z prawdą dokumentów.

Dla dokonywanej tutaj oceny pożytecznym mogą być także poniższe wskaźniki. Otóż z ogólnie dostępnych informacji wynika też, że Polska musi zwrócić do unijnego budżetu ponad 280 tysięcy euro w związku z nieprawidłowo wydatkowanymi środkami finansowymi z funduszy rolnych UE. ${ }^{44} \mathrm{~W}$ świetle tej informacji obowiązkiem takiego zwrotu objęto dotąd 20 unijnych krajów na sumę ponad $115 \mathrm{mln}$ euro. Z krajów tych najwięcej musiała zwrócić Wielka Brytania - prawie $30 \mathrm{mln}$ euro, następnie Włochy - ponad $21 \mathrm{mln}$ euro oraz Holandia - 14 mln euro. Najmniej natomiast do unijnego budżetu muszą zwrócić Dania i Malta - po tysiąc euro.

Jak widać z przytoczonych wyżej danych liczbowych, ilustrujących przykładowo tylko rozmiar nieprawidłowości w zakresie korzystania z funduszy unijnych i wynikające z tego tytułu skutki finansowe, skonkludować należy, że skala nieprawidłowości uzasadnia jednak potrzebę ciągłego doskonalenia sprawnego systemu dystrybucji unijnych środków budżetowych z jednej strony, z drugiej zaś zachodzi też konieczność nie tylko utrzymywania ale także ciągłego doskonalenia mechanizmów ochrony interesów finansowych UE.

W świetle tego co już wyżej powiedziano, Polska jako kraj z grupy największych beneficjentów środków budżetowych UE zasługuje na pozytywną ocenę w zakresie prawidłowego korzystania z pomocy unijnej. Nie oznacza to jednak, że $w$ tej sytuacji nasze krajowe instytucje uczestniczące w procesie dystrybucji unijnej pomocy mogą sobie pozwolić na spowolnienie swojej aktywności w zakresie doskonalenia działań w tym zakresie. Zagrożenie nieprawidłowym wydatkowaniem środków unijnych ciągle istnieje, a taki stan rzeczy niech potwierdzą opublikowane wyniki konferencji, odbytej w październiku 2008 roku w Ministerstwie Rozwoju Regionalnego, na temat: Wykrywanie i informowanie o nieprawidłowościach w wykorzystaniu funduszy europejskich w systemie realizacji Programu Infrastruktura i Środowisko - doświadczenia i wyzwania. ${ }^{45}$ Choć konferencja ta dotyczyła głównie funduszy pozarolniczych, to wypada zgodzić się z poglądem, że w procesie ich dys- 
trybucji jest wiele cech wspólnych, choćby nawet w zachowaniach beneficjentów unijnej pomocy. Zatem na użytek niniejszych rozważań może warto jeszcze będzie posłużyć się niektórymi zaprezentowanymi tam poglądami i danymi liczbowymi.

W pierwszej kolejności wypada wskazać na najczęściej przywoływane w materiałach konferencyjnych typy występujących nieprawidłowości ${ }^{46}$ Są nimi: niewykonanie współfinansowanego przedsięwzięcia, nadużycie bądź oszustwo, zrealizowanie przedsięwzięcia niezgodnie z przepisami oraz umową, naruszenia zasad dotyczących zamówień publicznych, wykazywanie wydatków niekwalifikowalnych, błędne rozliczanie nakładów oraz szereg innych. Do najczęściej występujących metod wykrywania tych nieprawidłowości zaliczyć należy: kontrolę na miejscu, kontrolę administracyjną, wizyty monitorujące, kontrolę skarbową, kontrolę ex post dokumentów. Warto jeszcze zwrócić uwagę na ustalenie, że w ponad $90 \%$ to nieprawidłowości mające miejsce już po uzyskaniu płatności przez beneficjenta. Wydaje się więc, że informacje powyższe powinny być uwzględniane nie tylko przy usprawnianiu procesu dystrybucji funduszy finansujących politykę spójności, ale również inne polityki UE, w tym także WPR.

Na zakończenie jeszcze jedna konstatacja. Otóż stosowanie sankcji za popełnione przez beneficjenta nieprawidłowości, zgodnie z zaleceniami KE, powinno być tak podejmowane, aby były one skuteczne, proporcjonalne do popełnionych nieprawidłowości oraz odstraszające. $Z$ drugiej strony sankcje te należy wprowadzać w takim zakresie, w jakim to jest konieczne dla zapewnienia stosowania prawa wspólnotowego, zwłaszcza pod kątem celowości i zgodności wydatków ze wspólnotowymi i krajowymi warunkami przyznawania pomocy. Warto jednak przy tej okazji zwrócić uwagę na rządzącą programami unijnymi zasadę, a wynikającą z przepisów regulujących różne formy unijnego wsparcia, zgodnie z którą w przypadku gdy pomoc została wypłacona nienależnie, zawsze podlega ona zwrotowi, niezależnie od tego, czy wina za jej zaistnienie leży po stronie beneficjenta, czy administracji. Zasadę tę, jak się wydaje, uznać jednak należy za kontrowersyjną, jeśliby poddać ją bardziej szczegółowej ocenie z różnych punktów widzenia. Jest to jednak zagadnienie na odrębny temat do rozważań, a w obowiązującym stanie prawnym pozostaje jedynie sformułować wniosek de lege lata, aby również instytucje administrujące funduszami unijnymi dopuszczały się w swych działaniach jak najmniej zawinionych przez siebie nieprawidłowości. 
SELECTED ISSUES OF PROTECTION OF THE EUROPEAN UNION'S FINANCIAL INTERESTS REGARDING COMMON AGRICULTURAL POLICY

Key words: common agricultural policy, implementation, EU's budget.

The disbursement of funds of the European Union's budget with regard to Common Agricultural Policy imposes on administrative authorities of Community and Member States many responsibilities to protect financial interests of the EU's budget. This paper presents the characteristics of these responsibilities and legal consequences of their violations and deals only with issues connected with responsibilities of domestic authorities. A well- functioning system of protection of such interests consists of a group of institutional guarantees starting with the effectively functioning institutions at the level of coordination, management and implementation of UE's aid, through effective management and control system dealing with disbursement of these funds. The effectiveness of the protection of those interests in particular Member States can be assessed by ascertained irregularities. Although Poland is considered to be a country which effectively deals with above mentioned protection of financial interests, it does not exempt our country form the obligation of further development in these area. 